\title{
Protected Areas in the Brazilian Semi-Arid and the Management and Conservation of Ecosystems
}

\author{
Clecia Simone G. R. Pachecoํ, Reinaldo Pacheco dos Santos ${ }^{2}$ Izabel P. R. de \\ Araújo $^{3}$
}

\author{
${ }^{1}$ Department of Food Technology of the Federal Institute of Sertão Pernambucano Brazil \\ ${ }^{2}$ Department of Geography of the University of Pernambuco, Brazil \\ ${ }^{3}$ Department of Chemistry of the Federal Institute of Sertão Pernambucano, Brazil
}

\begin{abstract}
The use of biodiversity has not been done sustainably on the planet, especially in South America, which has caused irreversible environmental impacts. Geodiversity is an important component of the existing natural heritage, but it lacks studies that mainly exploit the characteristics of the landscape and its forms of conservation. In this way, the aim is to discuss the relevance of the sustainable use of natural resources of protected areas of the Brazilian semi-arid, especially of the paleodunate areas, as well as to present a proposal for the management and conservation of these areas in accordance with the realities investigated, based on renowned theorists, in the existing legislations and above all, based on the practical investigations carried out. Therefore, it is crucial to understand the relevance of the adequate management of Brazil's protected areas, especially those that have environmental indicators from other geological eras and that, once destroyed, will never be recomposed, since it is a dynamic complex, thus requiring greater attention and a coherent management for its actual conservation.
\end{abstract}

Keywords - Conservation, Brazilian semi-arid, Management, Protected areas.

\section{INTRODUCTION}

The political framework related to the creation and management of conservation units in Brazil is established in Law No. 9,985, which in July 2000 established the System of Conservation Unit (SNUC). The preparation of a system of conservation units in Brazil began in 1976, in a paper called "An analysis of priorities in nature conservation in the Amazon", which based the preparation of the National System of Conservation Units Plan of Brazil, published between 1979 and 1982 (MERCADANTE, 2001).

This document proposed the immediate creation of National Parks, Biological Reserves and National Forests in the region, invariably in areas rejected by the planned economic projects. In fact, between 1979 and 1985, 10 (ten) National Parks were created, 04 (four) of which in the Amazon; 13 Biological Reserves, five of them in the same region, and 15 (fifteen) Ecological Stations, 11 (eleven) in the Amazon, totaling 20 (twenty) conservation units of integral protection in that part of the country, or 9.7 million of hectares (BARRETTO, 2003).

In 1988, the year of the promulgation of the current Constitution, the federal government commissioned a critical evaluation of the categories of conservation units existing in the country and the preparation of a preliminary bill to establish a national system of conservation units. In May 1992, a proposal was sent as a Bill to the National Congress, finally being approved. On July 19, Law No. 9,985/2000 was published, which instituted the SNUC (MERCADANTE 2001).

Based on these premises, it can be affirmed that the National Strategic Plan for Protected Areas (PNAP) in Brazil was created in 2005 with a Ministerial Working Group composed of specialists, managers of conservation units and leaders of organizations of the civil society and social movements, being that only in April of the following year, the PNAP was officially instituted through Decree No. 5,758. The PNAP defined principles, guidelines, objectives and strategies for Brazil to establish a comprehensive system of protected areas, ecologically representative and effectively managed, integrating broader terrestrial and marine landscapes by 2015 .

However, from 2015 to the present, the index of environmental impacts has grown in Brazil, especially in the Semi-arid region, even though it has numerous legal documents that protect natural areas. In this context, this research aimed to discuss the relevance of the sustainable use of natural resources of protected areas of the Brazilian semi-arid, especially of the paleodunares fluvial areas, as well as present a proposal for the management and 
conservation of those areas in accordance with the realities investigated, based on in the theories, in the existing legislations and above all, based on the practical investigations carried out.

The methodology is based essentially on the Geosystemic Theory (SOTCHAVA, 1977), the Ecodynamic Method (TRICART, 1977) and, in the Geosystem - Territory Landscape Theory (GTP) of Bertrand and Bertrand (2007). Therefore, it is crucial to develop conservation measures for protected environments, since landscapes are products and records of the geological evolution of the planet and integrate the planet (LOPES, ARAÚJO, 2011), as well as corroborate for the sustainable use of the biome. Thus, it is essential to understand the urgency of the adequate management of protected areas in Brazil, essentially those that protect environmental indicators of paleoeras, paleoclimates and paleoventos.

The article is divided into four iten, such as: 1. Introduction, 2. Theoretical contribution that deals with management of ecosystems in conservation units, where it is approached conservation units of Caatinga - semiarid brasileiro, conservation unit dunas do São Francisco and categorization of dune areas. 3. Methodology, disjunction the path traveled by research and theories of support. 4 . Resulted, which addresses relevance of conservation units for the environment, and environmental conservation plan for the dunes and landscapes of the middle São Francisco. Finally, we have the conclusions and bibliographical references.

\section{THEORETICAL FRAMEWORK}

\subsection{LEGAL FRAMEWORK FOR PROTECTED}

\section{AREAS}

Although a relevant part of the current normative framework regarding protected areas in Brazil has been instituted in the last ten years, there are structuring norms of the national policy that came into force before that period. It is a specific case of Law No. 6,938, which in 1981 established the National Environmental Policy; of the Federal Constitution, enacted in October 1988, and other important laws for the planning and management of protected areas (BRASIL, 1998).

Among the many environmental protection laws, the laws that make up the legal framework for the current policy of protected areas in the country are described in chronological order below:

i. $\quad$ Law $N^{\circ} 4.771 / 1965$ (Forest Code): when the Forest Code was instituted, Law $\mathrm{N}^{\circ}$. 4.771, of September 15, 1965 and its subsequent amendments, brought to the Brazilian legislation the figures of the areas of permanent preservation (APP) legal reserve, whose vegetation must be kept free of low cut depending on the role they play for the maintenance of ecological services. According to the Forest Code, the forests that make up the indigenous patrimony are subject to the regime dispensed to the PPA areas (BRASIL, 1965).

ii. Decree $n \circ 84,017 / 1979$ : published on 09/21/79, approves the regulation for National Parks (BRASIL, 1979).

iii. Law $\mathrm{n}^{\circ}$ 6,938/1981: approved on 08/31/1981, instituted the National Environmental Policy, establishing as a principle "the governmental action in the maintenance of the ecological balance, considering the environment as a public patrimony to be necessarily insured and protected, taking into account the collective use "(article 2, paragraph I) (BRASIL, 1981).

iv. Federal Constitution of 1988: enacted in 1988, establishes that "everyone has the right to an ecologically balanced environment, well-used by the people and essential to a healthy quality of life, imposing the duty of defending public authority and the community, and preserve it for present and future generations "(article 225) (BRASIL, 1988).

v. Decree No. 99.274/1990: that decree, of 06/06/90, regulates the law of the National Environmental Policy, specifying that its execution will be carried out when the Public Power, in the different levels of government, "protect the areas representative of ecosystems through the implementation of conservation units [...] "(article 1, paragraph II) (BRASIL, 1990).

vi. Decree No. 1,298/1994: published on October 27, 1994, approves the National Forest Regulation (BRASIL, 1994).

vii. Convention on Biological Diversity (CBD): the CBD was signed by the President of the Republic during the United Nations Conference on Environment and Development in June 1992 and was ratified by the National Congress through Legislative Decree No. 2/94, In accordance with Decree No. 2.519, on 03/17/98, and promulgated through Decree No. 2.519. Brazil, in its capacity as signatory, has followed its principles and determinations, with special attention to Article 8, which deals with in situ conservation, and Article 6, which defines measures for the conservation and sustainable use of biodiversity. The PNAP meets the commitments assumed by Brazil under the $\mathrm{CBD}$, in particular, those derived from Decision VII / 28 and VII/5 (BRASIL, 1998).

viii. Law $n^{\circ}$ 9.985/2000: created the SNUC, composed of defined territorial spaces and their respective environmental resources that have relevant natural characteristics, legally established by the Public 
Power, with conservation objectives and under a special administration regime, called conservation units (BRASIL, 2000).

ix. Decree No. 4,340/2002: regulated articles of Law No. 9,985/2000 (SNUC) relating to the following topics: creation of conservation unit, definition of subsoil limits and airspace of the conservation unit, creation and operation of mosaic of management units, operation of advisory and deliberative councils, shared management with civil society organizations of public interest, authorization for the exploitation of goods and services in conservation units, compensation for significant environmental impact, resettlement of traditional resident populations in units of conservation, reevaluation of unit of conservation of nonexistent category in the SNUC, operation of the Biosphere Reserves (BRASIL, 2002).

x. Decree No. 4.339/2002: published on 08/22/2002, established the principles and guidelines for the implementation of the National Biodiversity Policy, considering the commitments assumed by Brazil in the CBD to develop strategies, policies, plans and programs of biodiversity and the other existing norms related to the subject (BRASIL, 2002).

xi. Decree No. 4,703/2003 and amendments: published on 05/21/2003, provides for the National Program for Biological Diversity (Pronabio) and the National Commission for Biodiversity (Conabio). The Pronabio's main objective is to promote collaboration between the Public Power and civil society in the conservation of biodiversity, the sustainable use of its components and in the fair and equitable sharing of the benefits derived from such use (BRASIL, 2003).

xii. Decree No. 5.092/2004: this Decree, of 21/05/2004, defines rules for the identification of priority areas for the conservation, sustainable use and distribution of the benefits of biodiversity, within the framework of the powers of the Ministry of Environment Ambient (BRASIL, 2004).

xiii. Decree n. 5.746/2006: published on 04/05/06, approves regulations for the Particular Reserves of the National Patrimony (BRASIL, 2006).

xiv. Decree $n \circ$ 5,758/2006: published on 04/13/06, institutes the National Strategic Plan for Protected Areas - PNAP, its principles, guidelines, objectives and strategies, and provides other measures (BRASIL, 2006).

$\mathrm{xv}$. Law $\mathrm{N}^{\circ}$ 11.428/2006 (Atlantic Forest Law): when establishing the use and protection of the native vegetation of the Atlantic Forest biome, this law establishes the definition of the biome and conditions for its conservation, economic use and recovery, and that it is the most dramatically reduced Brazilian biome, with less than $8 \%$ of its original vegetation (BRASIL, 2006).

xvi. Law No. 11,516/2007: published on 08/28/07, created the Chico Mendes Institute for the Conservation of Biodiversity - Chico Mendes Institute, a federal autarchy linked to the Ministry of the Environment (BRASIL, 2007).

Regarding this history of laws and regulations built in Brazil over decades, it is possible to affirm that, it is not for lack of legislation that environmental areas are not being protected as they should be, but because of the absence of a strong control and by the lack of political will, since currently, all legislation that must be strengthened is being revised to "loosen up" and simplify processes, thus leaving the natural environment even more unprotected and accessible to the exploitation of all nature.

\section{MANAGEMENT OF ECOSYSTEMS IN CONSERVATION UNITS \\ 2.1 CONSERVATION UNITS OF CAATINGA - SEMIÁRIDO BRASILEIRO}

The Caatinga is the only exclusively Brazilian biome and covers a territory of $734,478 \mathrm{~km} 2$ and although it is an exclusive Brazilian biome, much is left in the background in relation to its conservation (MMA, 2003). Although little known and/or studied, the Caatinga is rich in the diversity of endemic species, because of its climatic and soil conditions (MMA, 2002). However, much is known for wood and furniture exploitations, because of human actions.

The creation of Conservation Units (Figure 1) is today one of the main instruments for the conservation of biodiversity (BENSUASAN, 2006), aiming at the preservation in situ, which consists of the conservation of ecosystems and natural habitat and the maintenance and recovery of viable populations of species in their environments "(BRASIL, 2000). 


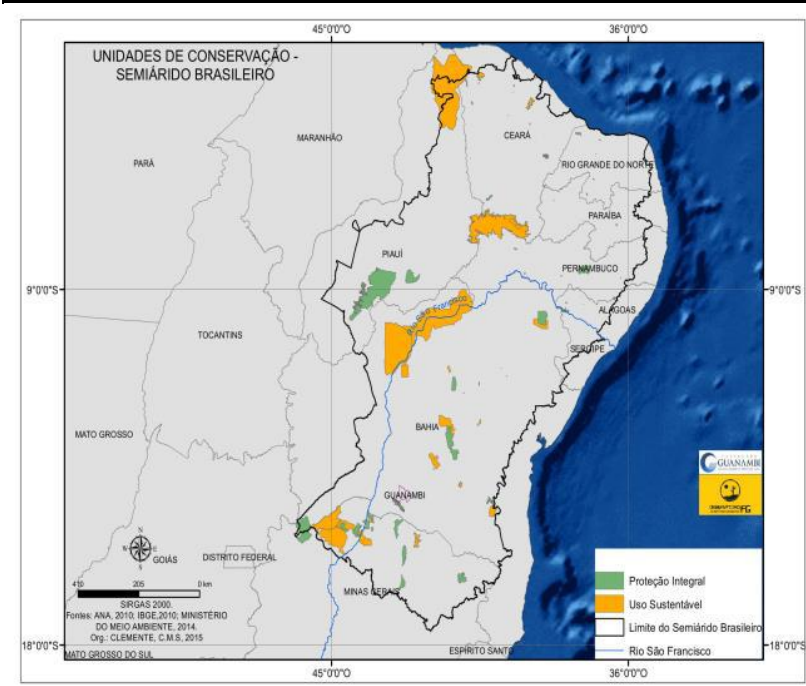

Fig. 1 - Conservation Units of the Brazilian Semi-Arid

Source: ANA; IBGE (2010); MMA (2014)

It can be seen then that the current network of Conservation Units in the Caatinga biome is insufficient to guarantee the maintenance of its biological diversity, being urgent the creation of new units, in addition to actions that enable the effective implementation and operation of the units existing.

The Caatinga biome is inserted in the morphoclimatic domain of the semiarid, which according to Souza (2000) has the sertões as typical geographic environments. In that region, erosion surfaces developed on crystalline rocks, originating from the pre-Cambrian period. One of the main characteristics of the semiarid sertões are the high temperatures and the rainfall irregularity, being the irregularity in the space and in the time the main mark of the semi-arid climate.

Historically, the exploitation of natural resources in the Brazilian Northeast (NEB), is practiced in an unsustainable way. Since the beginning of Brazilian colonization in the sixteenth century, the natural resources of the Brazilian semi-arid have been thoroughly exploited. It can then be verified that the current network of Conservation Units in the Caatinga biome is insufficient to guarantee the maintenance of its biological diversity, being urgent the creation of new units, in addition to actions that enable the effective implementation of existing units.

Table 1 presents the area and percentage of ecoregions of the Caatinga protected by public conservation units of federal and state administration, according to the protection group (integral protection, sustainable use).
Table 1 - Caatinga ecoregions protected by conservation units

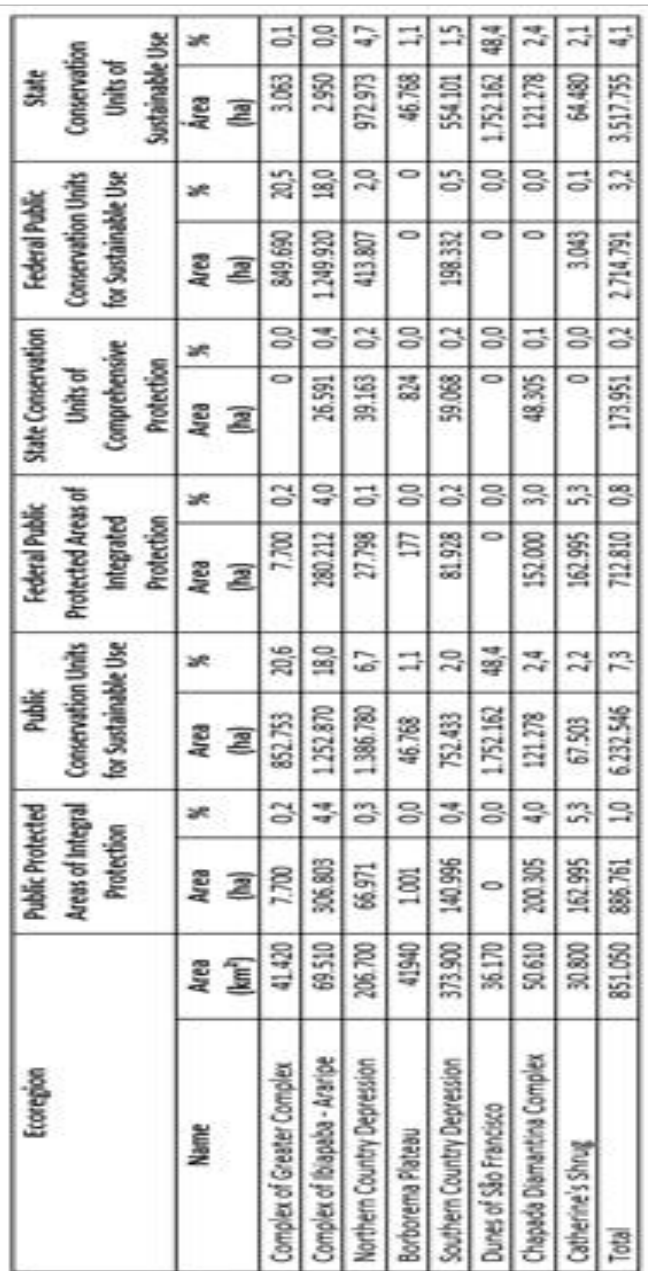

Source: Adapted PNUD (2010)

"Private Reserves of Natural Heritage" (RPPN) protect less than 50,000 hectares or $0.1 \%$ of the territory of ecoregions, while indigenous lands and other protected areas considered as priority areas by mapping 2007 contribute little more than 630 thousand hectares, representing less than $1 \%$ of ecoregions.

Research shows that protection rates are very low, except for those related to Environmental Protection Areas (APA), a category of management responsible for the high rates of the sustainable use group. Private reserves contribute to the protection of small areas and are distributed throughout all ecoregions, with Catherine's short having the smallest area and percentage of protection by these units.

Indigenous lands are found mainly in the ecoregions of Catherine's short, Plateau da Borborema and Campo Maior Complex. In the general context, the Borborema Plateau is the least protected ecoregion, both by indices and by the type of protection, which is essentially carried out by indigenous lands, whose primary objective is cultural, being that the conservation of nature in these areas, under current conditions, is not fully guaranteed. 
For this reason, it is recommended to prioritize the creation of integral protection conservation units in the ecoregions of the Borborema Plateau, Dunas of São Francisco, Campo Maior complex, Northern Sertaneja Depression, Southern Sertaneja Depression.

\subsection{CONSERVATION UNIT DUNAS DO SÃO FRANCISCO}

The Dunes and Sidewalks of Bajo-Medio San Francisco has an area of State Environmental Protection, belonging to the group of sustainable use, with an area of 1.085,000 hectares, created by Decree n. 6.547 of 07/18/1997, is sued by the government of the State of Bahia, having as its managing body the Secretariat of Environment and Resources (D.O.E/BA, 1997).

The APA Dunes and low-middle trails São Francisco is located in a region of semi-arid climate, with low rainfall, but the outcrop of the water table occurs at some points. The vegetation is rich, diversified and unique, composed of a transition between the Cerrado and the Caatinga. In this context, angico and aroeira bushes, lagoons, heather and extensive trails of buritis emerge. As well as the flora, the fauna of the APA also deserves highlight, even presenting some species of endemic reptiles and rodents. The region is a great attraction for scientists.

The São Francisco Dunes, despite the large area protected by environmental protection areas (APA), is the only ecoregion with no comprehensive protection unit. The Borborema Planalto is protected by four integral protection units, being a federal (PN Catimbau) and a state (PE del Pau Ferro) the main responsible.

The Ecoregion of the Campo Mayor Complex is barely protected by a comprehensive protection unit, the Seven Cities PN. Three federal ecological stations and three state parks are the units that protect the great Northern Sertaneja Depression ecoregion. The largest of them, the Depression Sertaneja Meridional, has its integral protection carried out mainly by four federal units and six state ones, of the park category in its majority.

According to Pacheco and Oliveira (2016) the dunes of the San Francisco are considered important ecosystems for hosting an odd biological diversity, composed of a flora rich in species and a fauna made up of insects, reptiles, amphibians, small mammals and some species of birds that They use the dunes to build their nests. Due to their importance, they are considered areas of environmental preservation, and then law, which forces the managing body to adopt land use and occupation plans and environmental management and conservation, protects them.

This geographical space suffers considerable remodeling by virtue of anthropogenic origins, causing modifications, in some cases, irreversible. Among the conditioning factors originating from dune environments are distinguishing elements that contribute to the process of dune destructiveness that are incorporated both to factors of an anthropic nature and to those correlated with the dynamics of the coastal elements acting on the site, which are listed as examples: the existence of the vegetation and its state of degradation, the frequency of the wind sands in the dune composition, the wind direction speed influencing dune addition/erosion processes, the seasonal variation of the rains, in addition to anthropogenic derivations as an advance of agricultural practices, vehicle traffic, in vulnerable areas, among others (PACHECO, OLIVEIRA, 2016).

\subsection{CATEGORIZATION OF DUNE AREAS}

The natural areas can be categorized according to the theory of Tricart (1977) in: stable areas, intergrades areas and unstable areas, being:

a) Stable - where pedogenetic processes supplant the mechanical processes in the evolution of modeling. According to Tricart (1977, p. 36) "the conditions are close to what the phytoecologists designate by the term climax". The media considered to be morphodynamically stable have a sufficiently closed plant cover to avoid triggering the mechanical processes of morphogenesis.

b) Intergrades - that are areas of transition and in these, morphogenesis and pedogenesis act mutually in the dynamics of the landscape. These means, in effect, ensure the gradual passage between stable and unstable media. What characterizes these media is the permanent interference of morphogenesis and pedogenesis, exercising concurrently over the same space. On the other hand, Tricart (1977, p. 51) affirms that "the intergrades media are delicate and susceptible to phenomena of amplification, transforming themselves into unstable media whose exploitation is compromised".

c) Unstable - where there is a predominance of morphogenetic processes versus pedogenetic processes, either by factors of a natural nature or due to anthropic causes. There are several processes that contribute to a greater susceptibility of these media. One of them is the vegetation, because it intervenes introducing an indirect influence of the climate, being the greatest instability realized in the regions that present strong climatic instabilities. In that case, part of the vegetation is poorly adapted to climatic irregularities and biostatic influences are reduced to a minimum.

In this sense, anthropic degradation adds natural causes, particularly effective in rugged regions where the climate has severe limiting factors to the vegetation. Such difficult ecological conditions make degradation easier, preventing the reconstitution of vegetation in certain periods. 
III. METHODOLOGY

The present investigation is classified according to Gil (1999), Andrade (2006), and Cervo et al. (2007), according to its nature, its technical procedures, the approach to the problem and the objectives. Regarding the approach to the problem, it is a qualitative research, since it considers the existence of a dynamic relationship between the real world and the subject, being descriptive and using the inductive method, being that the obtained data are analyzed indutively.

This study was based methodologically on the morphodynamic approach elaborated by Tricart (1977) and on the GTP method (Geosystem - Territory Landscape) of Bertrand and Bertrand (2007) to trace an analysis of the environmental dynamics of the study area. Preliminarily a systematic bibliographic analysis was made, seeking to characterize in a general way the dune environment of the San Francisco lowlands and the processes of degradation and/or conservation of those environments.

The adopted method of Tricart (1977) allows identifying the morphodynamic processes responsible for the genes is of the relief to the environmental stability of that landscape, submitting to the analysis of crucial parameters, such as surface structure of the dune field, land use, vegetation and surface processes.

The GTP method (Geosystem - Territory - Landscape), which is relevant not only for the delimitation and cartographic representation of the areas, but essentially for the detection of the existing problems in the premises and the degree of responsibility of the anthropogenic action on them, as well as, the planning of strategies to contain, reverse or enliven the impacts already provoked in the environments studied. Thus, this methodology envisages the search for the sustainable management of natural resources, which seeks to lead sciences to the understanding of the functioning of landscape units, in their naturalistic/social/cultural whole.

\section{RESULTS}

\subsection{RELEVANCE OF CONSERVATION UNITS FOR}

\section{THE ENVIRONMENT}

The formation of preserved areas known as Units of Conservation (UC) is considered of extreme importance in the preservation of ecosystems, providing a concrete possibility of conservation and protection of the environment, being an environmental public policy, apparently, federal level. Through the defense of natural resources, these Units have the main objective of protecting biodiversity under special State protection (SILVA, et al, 2017).

The formation of preserved areas, currently known as the Conservation Unit (UC), is considered of significant importance in the preservation of ecosystems, providing a continuous search for conservation and protection of the environment. The creation of these spaces has been signed in Brazil and in the world, as the fundamental and most diffuse strategy of protecting nature and defending natural resources. The main objective of these Units is to protect biodiversity under special State protection (SILVA, et al, 2017).

According to the National Cadaster of Conservation Units (CNUC), there are currently about 1,113 Conservation Units in Brazil, and the growth of these territorial spaces is increasingly frequent, with the objective of preserving fauna, flora and abiotic factors, in that they have defined limits under a special administration regime, to which adequate guarantees of protection apply.

It is ensured and obligatory by the SNUC, in its article 27, that each UC has a management plan. According to the SNUC, the management plan is about one:

Technical document through which, based on the general objectives of a Conservation Unit, is established its zoning and the rules that should preside over the use of the area and the management of natural resources, including the implementation of the physical structures necessary for the management of the Conservation Unit (Article 2, paragraph XVII).

In the case of integral protection units, this planning and management tool should contemplate a buffer zone and ecological corridors, which include measures that promote the protection of biodiversity and integrating the units to the economic and social life of the communities neighbors. By establishing standards, guidelines, programs and zoning of the UC, the document helps in the allocation and obtaining of resources for the implementation of proposed measures and interventions. As determined by CONAMA Resolution No. 347, of September 10, 2004, Conservation Units that present natural underground cavities destined for public visitation also need Speleological Management Plans (SMEs) (BRASIL/CONAMA, 2012).

The positioning of Silva stands out; Bonilla; (2011) when affirming that "the absence of management plans in the UCs, is the result of the difficulty in effecting the agrarian regularization of the areas, because they lack resources and the process is also quite slow" (p. 53). In addition to the extensions are not selected by the technical-scientific method, but by political-economic pressures, interfering in environmental monitoring activities (SILVA, BONILLA, BIRTH, 2011). 
4.2 ENVIRONMENTAL CONSERVATION PLAN FOR THE DUNES AND LANDSCAPES OF THE LOWER MIDDLE SÃO FRANCISCO

The possible preservation proposals in the dune geosystem are totally based on the characteristics of the ecoregion, since it is inserted in an Environmental Protection Area. In this conviction, it is suggested the creation of three strategic plans, for the three environments and, according to the characteristics of the GTP. In this way an Environmental Conservation Plan (PCA) is proposed for the dune area, based on the application of plans for each area categorized from the conception of Tricart (1977), namely:

Table 1- Environmental Conservation Proposal

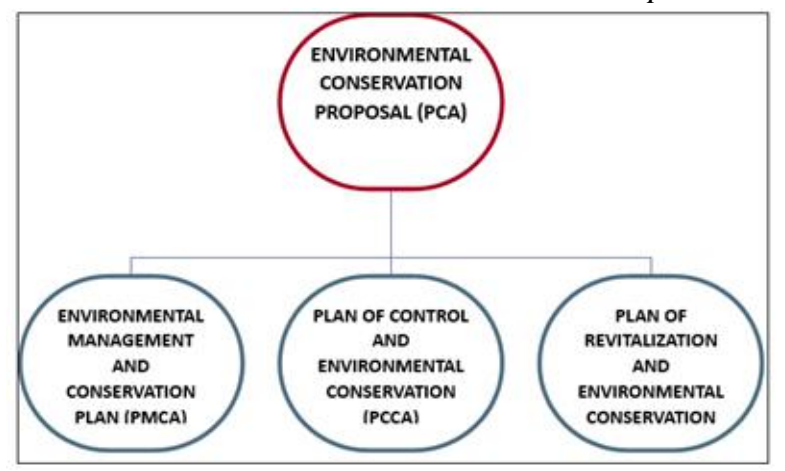

Suerce: Pacheco (2019)

The Environmental Management and Conservation Plan oriented towards the areas that still present themselves as stable, so that these are not seen in the future totally damaged because it is a fragile and vulnerable environment due to climatic and socioeconomic conditions.

The Environmental Conservation and Control Plan - this would be applied to areas that are in transition from stable aspect to middle intergrades. It is necessary to create degradation control strategies in the areas in process and strategies to conserve what remains of some fragments.

The Plan of Revitalization and Environmental Conservation - in this one is primary by strategies of revitalization/reforestation of the areas considered as strongly unstable and, from the results would be a control of preservation, analyzing the resilience capacity of the respective environments.

The proposals suggested above should start with those responsible for the management of the PAs, in the case of the Dunes and Veredas of the low and medium São Francisco, by the Government of the State of Bahia, in association with the municipalities affected by the impacts, where are located the fields of dunes. In addition to the municipalities, a partnership with the community is essential, since it is these subjects who are living together in that context, and can contribute positively to this awareness.

\section{CONCLUSIONS}

It is evident that the caatinga, due to the historical processes of use and occupation and also by the fragility of its natural environments, has suffered during the last five centuries a deep process of alteration of its natural conditions.

This degradation has contributed to the advance of desertification in some regions of the Northeast of Brazil. However, despite the semiarid condition, the Caatinga biome presents a series of peculiar conditions, since among those of the semi-arid regions dispersed by the planet is only present in the brazilian territory. In addition, the caatinga shelters a great diversity of species of both the fauna and the flora, being in great part endemic of the Brazilian Northeast.

Therefore, the Conservation Units of the biome are still insufficient to guarantee the effective conservation of its natural aspects, these already in an advanced degree of alteration by the human activities.

\section{REFERENCES}

[1] MERCADANTE, M. Uma década de debate e negociação: a história da elaboração da lei do SNUC. In: BENJAMIN, A. H. (org). Direito Ambiental das Áreas Protegidas: o regime jurídico das unidades de conservação. Rio de Janeiro: Forense Universitária, 2001. p. 190-231.

[2] BARRETTO FILHO, H. T. Da nação ao planeta através da natureza: uma abordagem antropológica das unidades de conservação de proteção integral na Amazônia Brasileira. São Paulo: FFLCH/ USP, 2001. Tese de Doutorado em Antropologia Social.

[3] SOTCHAVA, V. B. O estudo de geossistemas. São Paulo: Instituto de Geografia USP: 1977, 51 p. (Métodos em Questão, 16).

[4] TRICART, J. Ecodinâmica. Rio de Janeiro, IBGESUPREN, 1977.

[5] BERTRAND, G.; BERTRAND C. Uma Geografia Transversal e de Travessias: o meio ambiente através dos territórios e das temporalidades. Maringá: Mossoni, 2007.

[6] LOPES, L. S. de O.; ARAÚJO, J. L. L. Princípios e Estratégias de Geoconservação. OBSERVATÓRIUM: Revista Eletrônica de Geografia, v. 3, n. 7, p. 66-78, 2011.

[7] BRASIL. Constituição da República Federativa do Brasil de 1988. Disponível em: http://www.planalto.gov.br/ccivil_03/constituicao/co nstituicao.htm. Acesso em: 28/04/2019. 
[8] BRASIL. Lei $\mathrm{N}^{\circ}$ 4.771, de 15 de setembro de 1965. Institui o Novo Código Florestal. Disponível em: http://www.planalto.gov.br/ccivil_03/leis/14771.htm. Acesso em: 28/04/2019.

[9] BRASIL. Decreto No 84.017 , de 21 de setembro de 1979. Aprova o Regulamento dos Parques Nacionais Brasileiros. Disponível em: https://www2.camara.leg.br/legin/fed/decret/19701979/decreto-84017-21-setembro-1979-433347publicacaooriginal-1-pe.html. Acesso em: 28/04/2019.

[10] BRASIL. Lei $\mathrm{N}^{\circ}$ 6.938, de 31 de agosto de 1981. Dispõe sobre a Política Nacional do Meio Ambiente. Disponível em: http://www.planalto.gov.br/ccivil_03/leis/16938.htm. Acesso em: 28/04/2019.

[11] BRASIL. Decreto N. 99.274, de 6 de junho de 1990. Regulamenta a criação de Estações Ecológicas e Áreas de Proteção Ambiental e sobre a Política Nacional do Meio Ambiente. Disponível em: http://www.planalto.gov.br/ccivil_03/decreto/Antigos /D99274.htm. Acesso em: 28/04/2019.

[12] BRASIL. Decreto No 2.519, de 16 de março de 1998. Promulga a Convenção sobre Diversidade Biológica. Disponível em: http://www.planalto.gov.br/ccivil_03/decreto/d2519. htm. Acesso em: 28/04/2019.

[13] BRASIL. Lei $\mathrm{N}^{\circ}$ 9.985, de 18 de julho de 2000. Institui o Sistema Nacional de Unidades de Conservação da Natureza. Disponível em: http://www.planalto.gov.br/ccivil_03/leis/19985.htm. Acesso em: 28/04/2019.

[14] BRASIL. Decreto No 4.340, de 22 de agosto de 2002. Sistema Nacional de Unidades de Conservação da Natureza - SNUC. Disponível em: http://www.planalto.gov.br/ccivil_03/decreto/2002/d 4340.htm. Acesso em: 28/04/2019.

[15] BRASIL. Decreto No 4.339, de 22 de agosto de 2002. Implementação da Política Nacional da Biodiversidade. Disponível em: http://www2.mma.gov.br/port/conama/legiabre.cfm? codlegi=363. Acesso em: 28/04/2019.

[16] BRASIL. Decreto No 4.703, de 21 de maio de 2003. Dispõe sobre o Programa Nacional da Diversidade Biológica - PRONABIO e a Comissão Nacional da Biodiversidade. Disponível em: http://www.planalto.gov.br/ccivil_03/decreto/2003/d 4703.htm. Acesso em: 28/04/2019.

[17] BRASIL. Decreto $N^{\circ} 5.092$, de 21 de maio de 2004. Define regras para identificação de áreas prioritárias para a conservação, utilização sustentável e repartição dos benefícios da biodiversidade, no âmbito das atribuições do Ministério do Meio
Ambiente.

Disponível

http://www.planalto.gov.br/ccivil_03/_Ato2004-

2006/2004/Decreto/D5092.htm. Acesso em: 28/04/2019.

[18] BRASIL. Decreto $\mathrm{N}^{\circ}$ 5.746, de 5 de abril de 2006. Regulamenta o art. 21 da Lei no 9.985, de 18 de julho de 2000, que dispõe sobre o Sistema Nacional de Unidades de Conservação da Natureza. Disponível em: http://www.planalto.gov.br/ccivil_03/_Ato20042006/2006/Decreto/D5746.htm. Acesso em: 28/04/2019.

[19] BRASIL. Decreto No 5.758, de 13 de abril de 2006. Institui o Plano Estratégico Nacional de Áreas Protegidas - PNAP. Disponível em: http://www.planalto.gov.br/ccivil_03/_Ato20042006/2006/Decreto/D5758.htm. Acesso em: 28/04/2019.

[20] BRASIL. Lei No 11.428, de 22 de dezembro de 2006. Dispõe sobre a utilização e proteção da vegetação nativa do Bioma Mata Atlântica. Disponível em: http://www.sgc.goias.gov.br/upload/arquivos/201802/lei-no_-11_428-2006--lei-da-mata-atlantica.pdf. Acesso em: 28/04/2019.

[21] BRASIL. Lei No 11.516, de 28 de agosto DE 2007. Criação do Instituto Chico Mendes de Conservação da Biodiversidade - Instituto Chico Mendes. Disponível em: http://www.planalto.gov.br/ccivil_03/_Ato20072010/2007/Lei/L11516.htm. Acesso em: 28/04/2019.

[22] MINISTÉRIO DE MEIO AMBIENTE (MMA). Instrução Normativa No 003, de 26 de maio de 2003. Lista Nacional das Espécies da fauna brasileira ameaçadas de extinção. Disponível em: http://www.mma.gov.br/estruturas/179/_arquivos/17 9_05122008034002.pdf. Acesso em: 13/04/2019.

[23] MINISTÉRIO DO MEIO AMBIENTE (MMA). 2002. Biodiversidade brasileira. Avaliação e identificação de áreas e ações prioritárias para conservação, utilização sustentável e repartição dos benefícios da biodiversidade nos biomas brasileiros. Série Biodiversidade, v. 5. Brasília: MMA. 404 P.

[24] BENSUSAN, N. Conservação da Biodiversidade em Áreas Protegidas. Editora FGV, Rio de Janeiro, 2006.

[25] SOUZA, Marcos José Nogueira de. Bases Naturais e Esboço do Zoneamento Geoambiental do Estado do Ceará. In: LIMA, Luiz Cruz; MORAIS, Jáder Onofre de; SOUZA, Marcos José Nogueira de. Fortaleza: FUNECE, 2000.

[26] DIARIO OFICIAL DO ESTADO DA BAHIA (D.O.E.). Decreto No 6.547 de 18 de julho de 1997. Cria a Área de Proteção Ambiental das Dunas e Veredas do Baixo-Médio São Francisco, nos Municípios de Barra, Xique-Xique e Pilão Arcado. 
Disponível em: http://www.inema.ba.gov.br/wpcontent/uploads/2011/09/DECRETO-N\%C2\%BA-

6.547-DE-18-DE-JULHO-DE-1997-Dunas-e-

Veredas-do-Baixo-M\%C3\%A9dio-S\%C3\%A3o-

Francisco.pdf. Acesso em: 21/04/2014.

[27] PACHECO, C. S. G. R.; OLIVEIRA, N. M. G. A.. Caracterização histórico-ambiental da APA dunas e veredas do baixo-médio São Francisco (BA). Revista Ibero-Americana de Ciências Ambientais, v.7, n.2, p.29-44, 2016.

[28] GIL, Antonio Carlos. Métodos e técnicas de pesquisa social. 5. ed. São Paulo: Atlas, 1999.

[29] ANDRADE, Maria Margarida de. Introdução à Metodologia Científica: São Paulo: Editora Atlas, 2006.

[30] CERVO, Amado Luiz; BERVIAN, Pedro Alcino; DA SILVA, Roberto. Metodologia Científica. 6. ed. São Paulo: Pearson Prentice Hall, 2007.

[31] SILVA, J. I. A. O.; BARBOSA, E. S. L.; SILVA, A. G. F. da; NUNES, G. H. F. Unidades de conservação no Semiárido brasileiro: estudo da gestão desses espaços preservados. REUNIR, V. 7, n. 2, mai-ago. 2017. p. 48-66.

[32] BRASIL. CONSELHO NACIONAL DO MEIO AMBIENTE/BRASIL. Resoluções do Conama: Resoluções vigentes publicadas entre setembro de 1984 e janeiro de 2012. Ministério do Meio Ambiente. Brasília: MMA, 2012, 1126p.

[33] SILVA, Francisca Helena Aguiar; BONILLA, Oriel Herrera; NASCIMENTO, Camylla Alves. Avaliação da Viabilidade e Efetividade das Unidades de Conservação de Proteção Integral no Ceará, Brasil. Revista Caatinga, Mossoró, Brasil, v. 24, n. 1, p.4856, jan. 2011. 